\title{
IMPROVING YIELD AND FRUIT QUALITY OF WASHINGTON NAVEL ORANGE USING FOLIAR APPLICATIONS OF SOME NATURAL
} BIOSTIMULANTS.

El-Boray, M. S. ${ }^{1}$; M. F. M. Mostafa ${ }^{1}$; S. E. Salem ${ }^{2}$ and

O.A.O. El - Sawwah ${ }^{2}$

1. Pomology Dept., Fac.Agric., Mans. Univ., Egypt.

2.Citrus Res. Dept., Hort. Res. Inst., Agric. Res. Center, Giza, Egypt.

\begin{abstract}
Field experiment was carried out during two successive seasons of 2012 and 2013 on Washington Navel sweet orange cultivar (Citrus sinemsis, L) onto sour orange rootstock $(C$. aurantium, L) grown in well drainage clay loam soil of a commercial orchard located in Shiwah Valley $\left(30^{\circ} 51^{\prime} 55.78^{\prime \prime} \mathrm{N}, 31^{\circ} 16^{\prime} 23.14^{\prime \prime} \mathrm{E}\right)$, near Aga city, Dakahleia Governorate, Egypt. The investigation was designed to throw some light on the effect of two natural biostimulants, i.e., Milagrow at 10, 15 and 20 ppm (extracted from pollen grains of rape seed (Brassica napus) as a source of brassinolide phytohormone) and yeast extract at 1000, 1500 and 2000 ppm on fruit set, fruit drop, yield and fruit quality of Washington Navel orange trees. The natural biostimulants were tested as foliar sprays at full bloom stage and one month later.

Data indicated that, all biostimulants treatments increased fruit set, yield and fruit quality and decreased fruit drop as compared with control treatment. Data also revealed that, foliar sprays of trees by Milagrow at 15 and $20 \mathrm{ppm}$ were superior for inducing the highest increase of fruit set and yield, in addition yeast extract at 2000 ppm comparing with rest concentrations of both tested biostimulants. On the other hand, no significant differences were observed among all tested concentrations of two natural biostimulants with respect to fruit weight in two seasons. The foliar applications of Milagrow and/or yeast extract increased fruit SSC and reduced acidity contents in fruit juice as compared with control treatment. Moreover, it was noticed that trees sprayed with two tested biostimulants gave the best results for reducing fruit drop.

It could be recommended that best treatment for increasing yield and improving fruit quality was spraying Washington Navel sweet orange cultivar with Milagrow at $20 \mathrm{ppm}$ and yeast extract at $2000 \mathrm{ppm}$ during full bloom stage and one month later especially in the same conditions to experimental area.
\end{abstract}

Keywords: Washington Navel orange, brassinolide, yeast extract, yield, fruit quality.

\section{INTRODUCTION}

Citrus is one of the most prominent and important fruit crops at the local and global levels. Citrus is the backbone of fruit crop in Egypt. Since, its rank the first order among other fruits with 530.415 feddan represent $33.97 \%$ of total fruit cultivated area in Egypt. The total fruitful area of citrus reached about 440.706 feddan, which produce about 4.402 .180 metric tons according to Ministry of Agriculture, (2014). Washington Navel orange is the most favorite cultivar in Egypt and it is considered the popular fresh citrus fruits for the Egyptians due to its seedless, large size and flavor and aroma characteristic. Navel orange also is important source of early season income for citrus growers in some commercial citrus areas of the world. Yield is erratic and usually low in many areas due to lack functional pollen, rarely 
produce viable ovules and in addition, it is weakly parthenocarpic. Flower and fruit drop of Navel orange occurred in many phases and amount to more than $91 \%$, giving a fruit set less than $9 \%$ (Villafane et al., 1989). Agricultural biostimulants substances including, living microbes; extracts of microbes or plant origin; soil organic residues (humates and fulvates) and synthetic molecules. The mode of action of biostimulants is poorly understood and has been variously attributed to hormone composition, presence of plant signaling materials or presence of molecules that responsible for transport and uptake of mineral nutrients (Calvo et al., 2014).

There are many types of natural biostimulants like; yeast extract, seaweeds extract, algae extract and some plant parts extract which used as foliar application on fruit trees. Benefits of biostimulants substances may be due to its content of different nutrients, some common amino acids and some natural growth regulators. It is also contains proteins and large amount of vitamins. Which, play a key role in improving growth and controlling stresses producing healthier plants and increasing yield and its components. In addition, application of biostimulants is very effective in improving physiological and biochemical processes in fruit trees. Consequently, increasing net photosynthesis, flowering, fruiting and improving fruit quality (Kabeel et al., 2008; Khafagy et al., 2010; Kassem et al., 2010 and Barakat et al., 2012)

Biostimulants have been used in citriculture production with several objectives including bloom reduction, increased fruit setting, improvement of fruit quality and improved maturation control. Foliar application of these substances at fall-bloom and soon after petal-fall can resulted in delayed abscission and increased fruit set. In addition, it is very safe for human, animal and environment to get lower pollution and reduce soil salinity via decrease mineral usage fertilization as well as saving fertilization cost (ElShazly and Mustafa, 2013 and Abd El-Motty and Orabi, 2013).

Brassinolide are steroidal sixth group of phytohormones that are distributed in the plant kingdom. It was first purified and structurally determined from bee-collected rape (Brassica napus) pollen. Brassinolide had a wide range of physiological and molecular responses in plants, such as stem elongation, pollen tube growth, leaf bending, photosynthesis, ethylene biosynthesis, proton pump activation, vascular differentiation, gene expression, nucleic acid and protein synthesis (Sasse, 2003). The exogenous application of brassinolide in micromolar concentrations have wide-range of biological physiological and biochemical activities in various systems, from simple cells to whole plants, that increase the crop yields by changing plant metabolism and protecting plants from environmental stresses (Krishna, 2003).

The effects of brassinolide on growth and yield of Valencia orange studied by Wang et al. (2004). They reported that spraying brassinolide increased yield and improved fruit quality. Gabr et al. (2011) proved the role of brassinolide to accelerate yield harvesting on Canino apricot trees. Increasing yield per tree along with, fruit weight, length, diameter and size values were directly related to Milagrow concentrations. Brassinolide enhanced physiological status and directing trees to harvest earlier and 
improve fruit yield and quality of Canino apricot trees. The efficacy of brassinolide on fruit set, pollen germination and pollen tube growth of Carmel almonds (Prunus dulcis) trees was observed by Sotomayor et al. (2012). Spraying brassinolide onto flowering branches at full bloom stage improved fruit set and pollen germination.

Improving pollination process, yield and fruit quality of Samani date palm by Milagrow was established by Saleh et al. (2014). They revealed that mixture of Milagrow and pollen grains gave the highest fruit set and fruit retention percentages and yield as $\mathrm{kg} / \mathrm{palm}$ as well as the highest quality values. Roghabadi and Pakkish (2014) reported the effect of brassinosteroid on yield and fruit quality of sweet cherry (Prunus avium L.). Foliar applications at bud-swollen stage recorded the highest yield. Progressive increment of fruit weight, length, diameter and size was correlated to brassinolide concentrations. Using natural biostimulant ( Milagrow) for improving pollination efficiency, yield and fruit quality of Zaghloul and Samani date palm cultivars was reported by Hafez et al. (2014). They indicated that the highest fruit set and fruit retention percentages were achieved from combined Milagrow with pollen grains. In addition, the fruit quality expressed by fruit shape, volume, SSC, reducing and total sugars were markedly increased by Milagrow combined with pollen grains treatment.

Bread yeast (Saccharomyces cervisiae) as a natural biostimulant appeared to induce an astonished influence on growth and yield of many fruit crops, since it has various positive effects and benefits of applying yeast extract as a natural biofertilizer were attributed to its own different nutrients, greater amounts of vitamins $B_{1}, B_{2}$ and $B_{6}$ and cytokinin as natural plant hormone. In addition, application of active dry yeast was very effective in releasing carbon dioxide and stimulating photosynthesis (Mohamed and Hafez, 2004). Khafagy et al. (2010) tested yield and fruit quality of Navel orange in response to spraying yeast extract. The results showed that foliar application of yeast extract leads to increasing yield as well as physical and chemical characters of fruits rather than control.

Yeasts act as natural safety biofertilizer and rich source of phytohormones (especially cytokinins), sugars, vitamins, enzymes, amino acids and minerals. It was reported that yeast has stimulatory effects on cell division and enlargement, synthesis of protein and nucleic acid as well as chlorophyll formation. Improving growth and productivity of different plant species by application of yeast extract were recorded by Abou El-Yazied and Mady (2012).

In recent years, the world focused his attention to minimize the environmental pollution by reducing the use of synthetic fertilizers and chemicals in crops production. Therefore, several researchers tend to use environmentally safe organic substances and costless to encourage the productivity and quality of plant (Dawood et al., 2013). Therefore, the purpose of this work is to study the effect of Milagrow and yeast extract as natural biostimulants foliar application at different times and concentrations on yield and fruit quality of Washington Navel orange trees. Hence, to identify the best 
treatments for achieve the highest return for the growers under the experiment conditions.

\section{MATERIALS AND METHODS}

The present study was carried out during two successive seasons of 2012 and 2013 on Washington Navel orange cultivar (Citrus sinemsis, L) onto sour orange rootstock (C. aurantium, L). The tested trees were about 25years-old and approximately uniform in vigor and healthy in appearance grown in well drainage clay loam soil of a commercial orchard located in Shiwah Valley $\left(30^{\circ} 51^{\prime} 55.78 " \mathrm{~N}, 31^{\circ} 16^{\prime} 23.14 " \mathrm{E}\right)$, near Aga city, Dakahleia Governorate, Egypt. They spaced at $5 \times 5$ meters under surface irrigation system.

The investigation was designed to throw some light on the effect of some biostimulants on yield and fruit quality of Washington Navel orange trees. Two natural components, i.e., brassinolide phytohormone (Milagrow) from pollen grains of (Brassica napus) and yeast extract from Bread yeast (Saccharomyces cervisiae) were applied. Yeast extract was prepared by using a technique allowed yeast cells (pure dry yeast) to be grown and multiplied efficiently during conducive aerobic conditions that allowed to produce beneficial bioconstituent, (carbohydrates, sugars, proteins, amino acids, fatty acids, hormones, etc.), then these constituents could release out of yeast cells in readily form by two cycles of freezing and thawing for disruption of yeast cells and releasing their content. The yeast spraying solution was prepared according to the method described by Attala et al. (2000).

All treatments were applied twice; the first one at fall bloom stage and the last was done one month later. Triton B emulsifier at a rate of $0.2 \%$ was used with all spraying solutions before application as a wetting agent. Spraying was done till run off point using a hand pressure sprayer. The control trees were sprayed with tap water containing Triton B.

Table (1): Foliar application of natural substances with different concentrations on navel orange trees.

\begin{tabular}{|l|c|}
\hline Number & Treatment \\
\hline 1 & Control \\
\hline 2 & Milagrow at $10 \mathrm{ppm}$ \\
\hline 3 & Milagrow at $15 \mathrm{ppm}$ \\
\hline 4 & Milagrow at $20 \mathrm{ppm}$ \\
\hline 5 & Yeast extract at $1000 \mathrm{ppm}$ \\
\hline 6 & Yeast extract at $1500 \mathrm{ppm}$ \\
\hline 7 & Yeast extract at $2000 \mathrm{ppm}$ \\
\hline
\end{tabular}

This experiment consists of seven treatments arranged in a randomized complete block design and listed in Table (1). Three replicates were chosen for each treatment with two trees in each replicate. The tested 
trees were received the normal agricultural practices ordinary adapted in the commercial citrus orchards recommended in the experimental area.

Measurement of experimental data:

To study the responses of tested trees to different treatments, some fruiting parameters along with yield and fruit quality were measured as follow:

\section{A. Fruiting parameters:}

To determine the fruiting parameters including fruit set, fruit drop and fruit retention percentages along growth season, the emerged flowers on four labeled branches at different tree directions were counted at full bloom stage in both seasons. After fruit set, the setted fruitlets were counted at the same branches to calculate fruit set percentage by the following formula:

Fruit set $(\%)=\frac{\text { Total number of fruitlets }}{\text { Total number of flowers }} \times 100$

The remaining fruitlets on the same previous labeled branches were counted one month after petal fall to calculate the primary fruit drop percentage by the following formula:

Primary fruit drop $(\%)=\stackrel{\text { Total number of fruitlets- Number of fruitlets one month after petal fall] }}{\longrightarrow} 100$

Total number of fruitlets

Thereafter, the remaining fruits in the same branches were recounted by the end of June and December to calculate both June and total fruit drop and fruit retention percentages according to the following formulae:

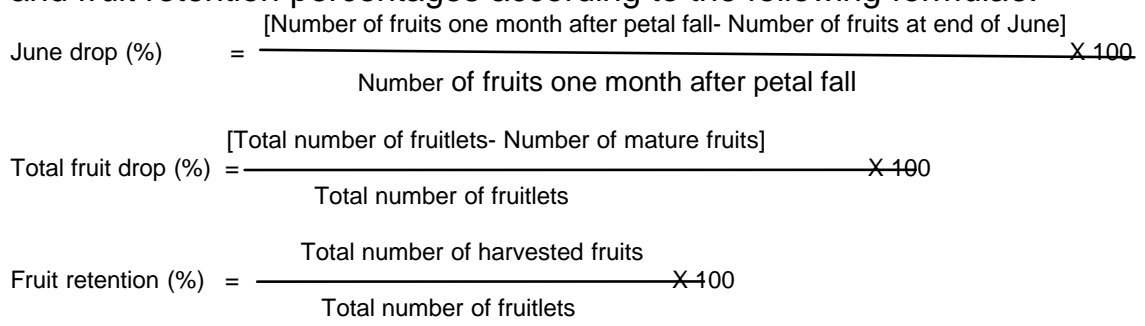

\section{B. Yield and its component:}

At the harvest time of each season the remained fruits as individual tree basis were picked and the average number of fruits per tree were recorded to determine yield as (Kg/tree) and (ton/feddan) by multiplication number of fruits per tree with an average fruit weight and yield per tree with the number of trees per feddan.

\section{Fruit quality parameters:}

At harvest time, a representative fruits sample was picked from each tested tree. Each sample counted 20 fruits, nearly uniform in size and free from obvious defects.

\section{Physical characteristics:}

Twenty mature fruits were taken from each replicate to determine the average fruit weight $(\mathrm{gm})$, fruit dimensions (diameter and length) $(\mathrm{cm})$, fruit volume $\left(\mathrm{cm}^{3}\right)$ and Juice volume $\left(\mathrm{ml}^{3}\right)$. 


\section{Chemical characteristics:}

Samples of fruits juice filtered through muslin cloth to determine the following chemical characteristics:

The percentage of soluble solids content (SSC) was expressed by using Carl-Zeiss hand Refractometer. Total acidity content percentage was determined by titrating $10 \mathrm{ml}$ juice from each sample against $\mathrm{NaOH}(0.1 \mathrm{~N})$ using phenolphthalein (ph.ph) as indicator, the acidity was expressed as citric acid percentage according to AOAC (1995). Soluble solids content (SSC)/acid ratio was calculated for all the samples by using following formula: SSC/acid ratio $=[$ SSC/Total acid contents $]$

Ascorbic acid content in fruit juice was determined by the dye method which essentially depends upon the oxidation of ascorbic acid with 2,6dichlorophenol indophenol dye. Vitamin c content was calculated as $\mathrm{mg} / 100$ $\mathrm{ml}$ juice according to AOAC (1995). Reducing, non-reducing and total sugars percentages were determined in juice by Shaffer and Somogyi method described by Ranganna (1979).

Statistical analysis:

The differences between the treatments and control were analyzed in completely randomized block design with three replicates for each treatment and each replicate was represented by two trees. The obtained data of both seasons were subjected to analysis of variance according to the means were differentiated using Duncan multiple range test at $5 \%$ level (Duncan, 1965). All statistical analyses were performed using analysis of variance technique by means of CoStat Computer Software.

\section{RESULTS AND DISCUSSION}

The effect of biostimulants on fruiting parameters:

The effect of biostimulants treatments on fruiting parameters of Washington Navel orange presented in Table (2).

Table (2): Effect of Milagrow and yeast biostimulants on fruit set (\%), final fruit set (\%) and fruit retention (\%) during 2012 and 2013 seasons.

\begin{tabular}{|l|c|c|c|c|c|c|}
\hline \multirow{2}{*}{ Treatments } & \multicolumn{2}{|c|}{ Fruit set (\%) } & \multicolumn{3}{|c|}{ Final fruit set (\%) } & \multicolumn{2}{|c|}{ Fruit retention (\%) } \\
\cline { 2 - 7 } & $\mathbf{2 0 1 2}$ & $\mathbf{2 0 1 3}$ & $\mathbf{2 0 1 2}$ & $\mathbf{2 0 1 3}$ & $\mathbf{2 0 1 2}$ & $\mathbf{2 0 1 3}$ \\
\hline Control & $21.70 \mathrm{~d}$ & $21.51 \mathrm{~d}$ & $2.11 \mathrm{e}$ & $2.06 \mathrm{f}$ & $0.93 \mathrm{~g}$ & $1.00 \mathrm{f}$ \\
\hline Milagrow at 10 ppm & $33.52 \mathrm{a}$ & $32.89 \mathrm{ab}$ & $2.80 \mathrm{c}$ & $2.86 \mathrm{c}$ & $4.36 \mathrm{c}$ & $4.49 \mathrm{~b}$ \\
\hline Milagrow at 15 ppm & $33.60 \mathrm{a}$ & $33.17 \mathrm{a}$ & $2.86 \mathrm{~b}$ & $2.94 \mathrm{~b}$ & $4.51 \mathrm{~b}$ & $4.80 \mathrm{a}$ \\
\hline Milagrow at 20 ppm & $33.67 \mathrm{a}$ & $33.30 \mathrm{a}$ & $3.00 \mathrm{a}$ & $3.01 \mathrm{a}$ & $4.82 \mathrm{a}$ & $4.83 \mathrm{a}$ \\
\hline Yeast extract at 1000 ppm & $32.05 \mathrm{c}$ & $32.15 \mathrm{c}$ & $2.69 \mathrm{~d}$ & $2.70 \mathrm{e}$ & $3.85 \mathrm{f}$ & $3.76 \mathrm{e}$ \\
\hline Yeast extract at 1500 ppm & $32.52 \mathrm{bc}$ & $32.28 \mathrm{bc}$ & $2.75 \mathrm{~cd}$ & $2.73 \mathrm{e}$ & $4.13 \mathrm{e}$ & $3.88 \mathrm{~d}$ \\
\hline Yeast extract at 2000 ppm & $32.90 \mathrm{abc}$ & $32.41 \mathrm{bc}$ & $2.77 \mathrm{c}$ & $2.81 \mathrm{~d}$ & $4.29 \mathrm{~d}$ & $4.26 \mathrm{c}$ \\
\hline
\end{tabular}

Means followed by the same letter in each column are not significantly different at the 0.05 $\%$ level of probability according to Duncan's multiple range test.

Generally, it can be observed that all biostimulants significantly increased fruit set and fruit retention percentages compared to control. Moreover, the effect of biostimulants in increasing fruit set and fruit retention percentages can be arranged as Milagrow at $20 \mathrm{ppm}$, Milagrow at $15 \mathrm{ppm}$, 
Milagrow at $10 \mathrm{ppm}$, yeast extract at $2000 \mathrm{ppm}$, yeast extract at $1500 \mathrm{ppm}$ and yeast extract at $1000 \mathrm{ppm}$ in descending order.

The highest final fruit set percentage was reached to 3.00 and $3.01 \%$ on trees sprayed with 20 ppm Milagrow solution in 2012 and 2013 seasons, respectively. Trees sprayed with 10 and $15 \mathrm{ppm}$ Milagrow recorded 2.80 and $2.86 \%$ along with 2.86 and $2.94 \%$ for final fruit set in the first and second seasons, respectively. The corresponding values for 1000,1500 and 2000 ppm yeast extract were 2.69, 2.75 and $2.77 \%$ as well as 2.70, 2.73 and 2.81 $\%$ in the two successive seasons of study.

Regarding the fruit drop percentages, the tabulated data in Table (3) revealed that tab water treatment recorded the highest values of all fruit drop parameters in both seasons of study.

Table (3): Effect of Milagrow and yeast biostimulants on primary fruit drop (\%), June drop (\%), pre harvest drop (\%) and total drop (\%) during 2012 and 2013 seasons.

\begin{tabular}{|l|c|c|c|c|c|c|}
\hline \multirow{2}{*}{ Treatments } & \multicolumn{2}{l|}{ Primary fruit drop (\%) } & \multicolumn{2}{l|}{ June drop (\%) } & \multicolumn{2}{c|}{ Total drop (\%) } \\
\cline { 2 - 8 } & $\mathbf{2 0 1 2}$ & $\mathbf{2 0 1 3}$ & $\mathbf{2 0 1 2}$ & $\mathbf{2 0 1 3}$ & $\mathbf{2 0 1 2}$ & $\mathbf{2 0 1 3}$ \\
\hline Control & $25.23 \mathrm{a}$ & $27.94 \mathrm{a}$ & $9.40 \mathrm{a}$ & $8.98 \mathrm{a}$ & $99.16 \mathrm{a}$ & $97.97 \mathrm{a}$ \\
\hline Milagrow at 10ppm & $20.24 \mathrm{e}$ & $19.42 \mathrm{~d}$ & $3.50 \mathrm{de}$ & $3.45 \mathrm{~cd}$ & $92.36 \mathrm{e}$ & $91.18 \mathrm{e}$ \\
\hline Milagrow at 15 ppm & $19.69 \mathrm{f}$ & $18.71 \mathrm{e}$ & $3.27 \mathrm{ef}$ & $3.26 \mathrm{~d}$ & $91.84 \mathrm{f}$ & $90.45 \mathrm{f}$ \\
\hline Milagrow at 20 ppm & $19.00 \mathrm{~g}$ & $18.20 \mathrm{e}$ & $3.09 \mathrm{f}$ & $3.19 \mathrm{~d}$ & $90.61 \mathrm{~g}$ & $89.86 \mathrm{~g}$ \\
\hline Yeast extract at 1000 ppm & $22.31 \mathrm{~b}$ & $20.82 \mathrm{~b}$ & $4.85 \mathrm{~b}$ & $4.09 \mathrm{~b}$ & $94.24 \mathrm{~b}$ & $92.59 \mathrm{~b}$ \\
\hline Yeast extract at 1500 ppm & $21.86 \mathrm{c}$ & $20.19 \mathrm{c}$ & $4.25 \mathrm{c}$ & $3.81 \mathrm{bc}$ & $93.71 \mathrm{c}$ & $91.96 \mathrm{c}$ \\
\hline Yeast extract at 2000 ppm & $20.77 \mathrm{~d}$ & $19.92 \mathrm{~cd}$ & $3.80 \mathrm{~d}$ & $3.65 \mathrm{bcd}$ & $93.10 \mathrm{~d}$ & $91.61 \mathrm{~d}$ \\
\hline
\end{tabular}

Means followed by the same letter in each column are not significantly different at the 0.05 $\%$ level of probability according to Duncan's multiple range test.

On the other hand, all tested biostimulants significantly decreased all studied fruit drops values. The results also proved the superiority of Milagrow treatments for reducing fruit drop percentages at all stages during the study comparing with yeast extract ones.

The primary fruit drop percentage ranged from 25.23 to $19.00 \%$ and 27.94 to $18.20 \%$ with control and $20 \mathrm{ppm}$ Milagrow treatments in the first and second seasons, respectively. The corresponding values of June drop were 9.40 to 3.09 and 8.98 to 3.19 . According to the results of total fruit drop percentage, the tabulated data showed that untreated trees recorded 99.16 and $97.97 \%$ in 2012 and 2013 seasons, respectively.

These results are in agreement with these reported by Sotomayor et al. (2012) with Carmel almond (Prunus dulcis) trees. They reported that foliar application of brassinolide achieved increase in fruit set in comparison to the control. Khafagy et al. (2010) came to the same results; they reported that spraying Washington Navel orange trees with $0.4 \%$ yeast extract two times yearly at flowering and after fruit set was more effective in improving fruit set and fruit retention. Also, Abd El-Motty et al. (2010) with Keitte mango trees and Abd El Hamied (2014) with Sukkary Mango trees reported that $0.2 \%$ and $0.3 \%$ yeast extract was very effective in improving fruit set and fruit retention as well as decreasing fruit drop percentage. 
The effect of biostimulants on yield and its components:

Yield and its components as influenced by spraying different concentrations of the tested substances in this work can be expressed as a number of fruits per tree and fruit weight in addition to crop by kilograms per tree and yield in tons per feddan.

Concerning the effect of foliar application of biostimulants on the number of fruits per tree for Washington Navel orange, the data in Table (4) showed the superiority of Milagrow treatments on yeast extract ones. It is also clearly indicated that, high concentrations of both tested biostimulants were positively affected more than low ones in both seasons.

Table (4): Effect of Milagrow and yeast biostimulants on fruits number, fruit weight $(\mathrm{gm})$, yield $(\mathrm{kg}) /$ tree and yield ton/feddan during 2012 and 2013 seasons.

\begin{tabular}{|l|c|c|c|c|c|c|c|c|}
\hline \multirow{2}{*}{ Treatments } & \multicolumn{2}{|c|}{ Fruits number } & \multicolumn{2}{|c|}{ Fruit weight (gm) } & \multicolumn{2}{c|}{ Yield (kg)/tree } & \multicolumn{2}{|c|}{ Yield (ton)/feddan } \\
\cline { 2 - 9 } & $\mathbf{2 0 1 2}$ & $\mathbf{2 0 1 3}$ & $\mathbf{2 0 1 2}$ & $\mathbf{2 0 1 3}$ & $\mathbf{2 0 1 2}$ & $\mathbf{2 0 1 3}$ & $\mathbf{2 0 1 2}$ & $\mathbf{2 0 1 3}$ \\
\hline Control & $404.66 \mathrm{e}$ & $404.49 \mathrm{e}$ & $179.61 \mathrm{~b}$ & $182.00 \mathrm{~b}$ & $72.68 \mathrm{e}$ & $73.62 \mathrm{e}$ & $11.62 \mathrm{e}$ & $11.77 \mathrm{e}$ \\
\hline $\begin{array}{l}\text { Milagrow } \\
\text { at 10 ppm }\end{array}$ & $463.45 \mathrm{~cd}$ & $471.27 \mathrm{~cd}$ & $204.38 \mathrm{a}$ & $206.54 \mathrm{a}$ & $94.72 \mathrm{~cd}$ & $97.33 \mathrm{~cd}$ & $15.15 \mathrm{~cd}$ & $15.57 \mathrm{~cd}$ \\
\hline $\begin{array}{l}\text { Milagrow } \\
\text { at 15 ppm }\end{array}$ & $467.01 \mathrm{c}$ & $475.04 \mathrm{bc}$ & $206.40 \mathrm{a}$ & $206.71 \mathrm{a}$ & $96.38 \mathrm{bc}$ & $98.19 \mathrm{bc}$ & $15.42 \mathrm{bc}$ & $15.71 \mathrm{bc}$ \\
\hline $\begin{array}{l}\text { Milagrow } \\
\text { at 20 ppm }\end{array}$ & $490.82 \mathrm{a}$ & $496.82 \mathrm{a}$ & $207.80 \mathrm{a}$ & $209.33 \mathrm{a}$ & $101.99 \mathrm{a}$ & $103.99 \mathrm{a}$ & $16.31 \mathrm{a}$ & $16.63 \mathrm{a}$ \\
\hline $\begin{array}{l}\text { Yeast extract at } \\
1000 \text { ppm }\end{array}$ & $457.94 \mathrm{~b}$ & $465.78 \mathrm{~d}$ & $204.41 \mathrm{a}$ & $207.28 \mathrm{a}$ & $93.60 \mathrm{~d}$ & $96.55 \mathrm{~cd}$ & $14.97 \mathrm{~d}$ & $15.44 \mathrm{~cd}$ \\
\hline $\begin{array}{l}\text { Yeast extract at } \\
1500 \text { ppm }\end{array}$ & $459.66 \mathrm{~cd}$ & $465.99 \mathrm{~d}$ & $205.75 \mathrm{a}$ & $206.66 \mathrm{a}$ & $94.57 \mathrm{~cd}$ & $96.30 \mathrm{~d}$ & $15.13 \mathrm{~cd}$ & $15.40 \mathrm{~d}$ \\
\hline $\begin{array}{l}\text { Yeast extract at } \\
\text { 2000 ppm }\end{array}$ & $475.33 \mathrm{~b}$ & $477.33 \mathrm{~b}$ & $206.41 \mathrm{a}$ & $208.40 \mathrm{a}$ & $98.11 \mathrm{~b}$ & $99.47 \mathrm{~b}$ & $15.69 \mathrm{~b}$ & $15.91 \mathrm{~b}$ \\
\hline
\end{tabular}

Means followed by the same letter in each column are not significantly different at the 0.05 $\%$ level of probability according to Duncan's multiple range test.

Data presented in the same table revealed that, all studied materials were significantly increased fruit weight comparing with control. The heaviest fruits resulted from trees sprayed with $20 \mathrm{ppm}$ Milagrow, followed by these resulted from $2000 \mathrm{ppm}$ yeast extract treatment in the two seasons. Different concentrations of tested biostimulants have insignificant effect on fruit weight. Fruits of trees sprayed with 10 and $15 \mathrm{ppm}$ Milagrow recorded weights of 204.38 and $206.40 \mathrm{gm}$ in the first season and 206.54 and $206.71 \mathrm{gm}$ in the second season. On the other hand, the lightest fruits resulted in untreated trees. Their reading values were 179.61 and $182.00 \mathrm{gm}$ in the first and second seasons, respectively.

As shown in Table (4), all studied treatments affected yield of Washington Navel orange trees in both seasons. The highest yield as kilogram per tree obtained from trees sprayed with $20 \mathrm{ppm}$ Milagrow (101.99 and $103.99 \mathrm{~kg} / \mathrm{tree}$ ) followed by those sprayed with $2000 \mathrm{ppm}$ yeast extract (98.11 and $99.47 \mathrm{~kg} / \mathrm{tree})$ in the first and second seasons, respectively.

According to the total yield as tons per feddan, the results take very similar trends with those obtained with yield per trees. The highest yield (16.31 and 16.63 ton/feddan) resulted from trees sprayed with $20 \mathrm{ppm}$ 
Milagrow in 2012 and 2013 seasons, respectively. Trees sprayed with 2000 ppm yeast extract as well as $15 \mathrm{ppm}$ Milagrow came in the second place with values of 15.69 and 15.91 ton /feddan along with 15.42 and 15.71 ton /feddan in the first and second seasons, respectively. In addition, the rest biostimulants treatments did not show significant differences with respect to total yield as ton per feddan throughout two years of study.

The present results agreed with these found by Atawia and ELDesouky (1997) on Washington Navel orange who showed that spraying yeast extract resulted in significant increase of the total fruits number, fruit weight and yield in Kg/tree. Hegab et al. (1997) with Valencia orange trees reported that carrying out two sprays of active bread yeast gave the best results with regard to fruit set, number of fruits, fruit weight and yield.

In addition, Ahmed and Ragab (2002) supported the beneficial effect of yeast on growth, yield and nutritional status of Picual olive trees. While, Wang et al. (2004) reported that brassinolide increased fruit weight of orange. In addition, spraying passion fruit trees with brassinolide increased fruit number per plant and in turn yield per hectare (Gomes et al., 2006). IbnMaaouia et al. (2012) on pepper found that, plants sprayed with 24-epibrassinolide at vegetative buds formation and early fruiting stages improved fruits number and yield per plant.

The effect of biostimulants on physical and chemical quality parameters:

The effect of foliar application with tested biostimulants on both physical and chemical quality parameters of Washington Navel orange during 2012 and 2013 presented in Tables (5, 6 and 7). Concerning the effect on fruit volume, fruit length, fruit diameter and juice volume, data in Table (5) clearly indicated that the biostimulant treatments gave positive effects for the previous parameters comparing with control in both seasons of study. The results in the same table showed that, trees sprayed with different concentrations of biostimulants resulted in larger fruit volume than control ones.

The largest fruit volume $\left(229.05\right.$ and $\left.229.29 \mathrm{~cm}^{3}\right)$ resulted from trees treated with ppm Milagrow in the two successive seasons. There are not significant differences among tested concentrations of yeast extract with respect to fruit volume. Fruit length and diameter measurements as affected by foliar application of biostimulants presented in the same table. 
Table (5): Effect of Milagrow and yeast biostimulants on fruit volume $\left(\mathrm{cm}^{3}\right)$, fruit length $(\mathrm{cm})$, fruit diameter $(\mathrm{cm})$ and juice volume $\left(\mathrm{ml}^{3}\right)$ during 2012 and 2013 seasons.

\begin{tabular}{|l|c|c|c|c|c|c|c|c|}
\hline \multirow{2}{*}{ Treatments } & \multicolumn{2}{|c|}{$\begin{array}{c}\text { Fruit volume } \\
\left(\mathbf{c m}^{3}\right)\end{array}$} & \multicolumn{2}{c|}{$\begin{array}{c}\text { Fruit length } \\
(\mathbf{c m})\end{array}$} & $\begin{array}{c}\text { Fruit diameter } \\
(\mathbf{c m})\end{array}$ & \multicolumn{2}{c|}{$\begin{array}{c}\text { Juice volume } \\
\left(\mathbf{m l}^{3}\right)\end{array}$} \\
\cline { 2 - 9 } & $\mathbf{2 0 1 2}$ & $\mathbf{2 0 1 3}$ & $\mathbf{2 0 1 2}$ & $\mathbf{2 0 1 3}$ & $\mathbf{2 0 1 2}$ & $\mathbf{2 0 1 3}$ & $\mathbf{2 0 1 2}$ & $\mathbf{2 0 1 3}$ \\
\hline Control & $195.14 \mathrm{e}$ & $196.02 \mathrm{e}$ & $7.05 \mathrm{f}$ & $7.53 \mathrm{~d}$ & $6.40 \mathrm{~b}$ & $6.43 \mathrm{~d}$ & $94.33 \mathrm{e}$ & $99.41 \mathrm{e}$ \\
\hline $\begin{array}{l}\text { Milagrow } \\
\text { at 10 ppm }\end{array}$ & $222.18 \mathrm{~d}$ & $223.18 \mathrm{~d}$ & $7.94 \mathrm{c}$ & $8.62 \mathrm{ab}$ & $7.65 \mathrm{a}$ & $7.96 \mathrm{~b}$ & $131.97 \mathrm{bc}$ & $139.91 \mathrm{c}$ \\
\hline $\begin{array}{l}\text { Milagrow } \\
\text { at 15 ppm }\end{array}$ & $225.38 \mathrm{c}$ & $227.48 \mathrm{~b}$ & $7.98 \mathrm{~b}$ & $8.70 \mathrm{a}$ & $7.68 \mathrm{a}$ & $8.06 \mathrm{a}$ & $133.84 \mathrm{~b}$ & $142.74 \mathrm{~b}$ \\
\hline $\begin{array}{l}\text { Milagrow } \\
\text { at 20 ppm }\end{array}$ & $229.05 \mathrm{a}$ & $229.29 \mathrm{a}$ & $8.10 \mathrm{a}$ & $8.73 \mathrm{a}$ & $7.70 \mathrm{a}$ & $8.11 \mathrm{a}$ & $138.21 \mathrm{a}$ & $145.37 \mathrm{a}$ \\
\hline $\begin{array}{l}\text { Yeast extract } \\
\text { at 1000 ppm }\end{array}$ & $226.46 \mathrm{~b}$ & $225.42 \mathrm{c}$ & $7.85 \mathrm{e}$ & $8.43 \mathrm{c}$ & $7.58 \mathrm{a}$ & $7.87 \mathrm{c}$ & $127.76 \mathrm{~d}$ & $134.58 \mathrm{~d}$ \\
\hline $\begin{array}{l}\text { Yeast extract } \\
\text { at 1500 ppm }\end{array}$ & $226.96 \mathrm{~b}$ & $226.55 \mathrm{bc}$ & $7.88 \mathrm{de}$ & $8.44 \mathrm{bc}$ & $7.60 \mathrm{a}$ & $7.93 \mathrm{bc}$ & $129.22 \mathrm{~cd}$ & $135.40 \mathrm{~d}$ \\
\hline $\begin{array}{l}\text { Yeast extract } \\
\text { at 2000 ppm }\end{array}$ & $227.50 \mathrm{~b}$ & $227.48 \mathrm{~b}$ & $7.91 \mathrm{~d}$ & $8.47 \mathrm{bc}$ & $7.63 \mathrm{a}$ & $7.95 \mathrm{~b}$ & $131.52 \mathrm{bc}$ & $136.88 \mathrm{~d}$ \\
\hline
\end{tabular}

Means followed by the same letter in each column are not significantly different at the 0.05 $\%$ level of probability according to Duncan's multiple range test.

The tabulated data proved that, both fruit length and fruit diameter were taking the same trend with fruit volume in both seasons under study. By other words, the biostimulant treatments recorded higher values than control.

The highest fruit juice volume resulted from trees received two sprays of $20 \mathrm{ppm}$ Milagrow followed by $15 \mathrm{ppm}$ of the same biostimulant with values of 138.21 and $133.84 \mathrm{ml}^{3}$ in the first season and 145.37 and $142.74 \mathrm{ml}^{3}$ in the second season, respectively. The yeast extract treatments showed insignificant effects on juice volume with respect to such tested concentrations.

Regarding the chemical quality parameters, data in Table (6) presented the effect of spraying biostimulants on soluble solid content percentage in Washington Navel orange fruit juice. The obtained results showed an obvious increasing in fruit juice (SSC \%) as affected by all tested foliar application treatments. The highest SSC percentage recorded in fruit juice resulted from trees sprayed with $20 \mathrm{ppm}$ Milagrow. It was 14.86 and $15.33 \%$ followed by these sprayed with $15 \mathrm{ppm}$ Milagrow, which gave 14.46 and $15.13 \%$ in the first and second seasons, respectively. Comparing the effect of yeast extract concentrations on SSC percentage, the obtained results clearly indicated insignificant differences among three tested concentrations in the first season along with, 2000 and $1500 \mathrm{ppm}$ in the second season.

The behavior of juice acidity measurement throughout the 2012 and 2013 seasons listed in Table (6). The tabulated data showed vice versa trends with those resulted in soluble solid content. The most acidic juice recorded with fruits resulted from control trees with values of 0.983 and 0.986 $\%$ in the two successive seasons. The titeratable acidity for juice of Washington Navel orange fruits under study can be arranged in descending order as control, Milagrow and yeast extract regardless the effect of different concentrations.

The effect of foliar applications of biostimulants on SSC/acid ratio of Navel orange fruit juice as presented in the same table was obvious that 
SSC/acid ratio of all treated fruits was significantly increased in both seasons comparing with control ones. Such increase makes Milagrow and yeast extract treatments take ascendancy place. The highest SSC/acid ratio resulted from $1500 \mathrm{ppm}$ yeast extract followed by $20 \mathrm{ppm}$ Milagrow treatment in the first season with values of 20.78 and 20.27 , respectively. The corresponded values in the second season were 21.25 and 20.69 which recorded with 20 and $15 \mathrm{ppm}$ Milagrow.

Table (6): Effect of Milagrow and yeast biostimulants on SSC, acidity (\%), SSC/acidity ratio and vitamin C ( $\mathrm{mg} / 100 \mathrm{ml}$ juice) during 2012 and 2013 seasons.

\begin{tabular}{|l|c|c|c|c|c|c|c|c|}
\hline \multirow{2}{*}{ Treatments } & \multicolumn{2}{|c|}{ SSC (\%) } & \multicolumn{2}{c|}{ Acidity (\%) } & \multicolumn{2}{c|}{ SSC/acidity ratio } & \multicolumn{2}{c|}{$\begin{array}{c}\text { Vitamin C } \\
\text { (mg/100ml juice) }\end{array}$} \\
\cline { 2 - 9 } & $\mathbf{2 0 1 2}$ & $\mathbf{2 0 1 3}$ & $\mathbf{2 0 1 2}$ & $\mathbf{2 0 1 3}$ & $\mathbf{2 0 1 2}$ & $\mathbf{2 0 1 3}$ & $\mathbf{2 0 1 2}$ & $\mathbf{2 0 1 3}$ \\
\hline Control & $11.50 \mathrm{e}$ & $11.63 \mathrm{f}$ & $0.983 \mathrm{a}$ & $0.986 \mathrm{a}$ & $11.70 \mathrm{~d}$ & $11.79 \mathrm{~d}$ & $42.95 \mathrm{e}$ & $42.89 \mathrm{e}$ \\
\hline $\begin{array}{l}\text { Milagrow } \\
\text { at 10 ppm }\end{array}$ & $14.20 \mathrm{c}$ & $14.77 \mathrm{c}$ & $0.763 \mathrm{~b}$ & $0.737 \mathrm{~b}$ & $18.60 \mathrm{c}$ & $20.03 \mathrm{c}$ & $54.68 \mathrm{c}$ & $54.46 \mathrm{~cd}$ \\
\hline $\begin{array}{l}\text { Milagrow } \\
\text { at 15 ppm }\end{array}$ & $14.46 \mathrm{bc}$ & $15.13 \mathrm{~b}$ & $0.752 \mathrm{~b}$ & $0.731 \mathrm{~b}$ & $19.23 \mathrm{bc}$ & $20.69 \mathrm{~b}$ & $56.45 \mathrm{~b}$ & $56.53 \mathrm{~b}$ \\
\hline $\begin{array}{l}\text { Milagrow } \\
\text { at 20 ppm }\end{array}$ & $14.86 \mathrm{a}$ & $15.33 \mathrm{a}$ & $0.733 \mathrm{bc}$ & $0.721 \mathrm{bc}$ & $20.27 \mathrm{ab}$ & $21.25 \mathrm{a}$ & $58.06 \mathrm{a}$ & $58.50 \mathrm{a}$ \\
\hline $\begin{array}{l}\text { Yeast extract } \\
\text { at 1000 ppm }\end{array}$ & $13.86 \mathrm{~d}$ & $13.86 \mathrm{e}$ & $0.696 \mathrm{~cd}$ & $0.685 \mathrm{~d}$ & $19.92 \mathrm{ab}$ & $20.24 \mathrm{bc}$ & $52.18 \mathrm{~d}$ & $53.53 \mathrm{~d}$ \\
\hline $\begin{array}{l}\text { Yeast extract } \\
\text { at 1500 ppm }\end{array}$ & $13.96 \mathrm{~cd}$ & $14.35 \mathrm{~d}$ & $0.696 \mathrm{~d}$ & $0.696 \mathrm{~d}$ & $20.78 \mathrm{a}$ & $20.62 \mathrm{bc}$ & $52.40 \mathrm{~d}$ & $54.83 \mathrm{c}$ \\
\hline $\begin{array}{l}\text { Yeast extract } \\
\text { at 2000 ppm }\end{array}$ & $14.00 \mathrm{~cd}$ & $14.53 \mathrm{~d}$ & $0.706 \mathrm{~cd}$ & $0.706 \mathrm{~cd}$ & $19.82 \mathrm{ab}$ & $20.57 \mathrm{bc}$ & $53.03 \mathrm{~d}$ & $54.92 \mathrm{c}$ \\
\hline
\end{tabular}

Means followed by the same letter in each column are not significantly different at the 0.05 $\%$ level of probability according to Duncan's multiple range test.

The tabulated data in the same Table pointed to the effect of Milagrow and yeast extract foliar applications on vitamin C content in juice of Navel orange fruits. The results indicated that all studied treatments increased vitamin C content in fruit juice. This behavior was more clear with fruits resulted from trees sprayed by Milagrow treatments than those by yeast extract ones in both seasons. The calculated values were expressed as $\mathrm{mg} / 100 \mathrm{ml}$ juice.

Comparing the effect of different Milagrow concentrations, the results show gradually increased in vitamin $\mathrm{C}$ content by concentration gradient of 10,15 and $20 \mathrm{ppm}$ with values of $54.68,56.45$ and $58.06 \mathrm{mg} / 100 \mathrm{ml}$ juice and $54.46,56.53$ and $58.50 \mathrm{mg} / 100 \mathrm{ml}$ juice in the two studied seasons, respectively. On the other hand, the vitamin $C$ content of fruits from trees sprayed with different concentrations of yeast extract was insignificantly affected.

Such results are in harmony with these reported by Abd El-Motty and Orabi (2013) on Navel orange they showed that yeast treatments increased soluble solids content (SSC \%), ascorbic acid (vitamin C) and total yield, but this treatments had decreased total acidity compared to untreated trees. They reported the useful effect of antioxidant materials for mitigating the harmful effects of oxidative stress through the enhancement of the protective antioxidant enzymes, ascorbic acid and total phenols and the decrease in 
membrane damage and consequently positively affected the quantity and quality of fruits and yield criteria.

Ismaeil and Bakry (2005) sprayed papaya plants with yeast extract and other solutions. As for yield, physical and chemical fruit quality, treatments of yeast extract followed by glucose gave highest values for different quality characteristics. Roghabadi and Pakkish (2014) reported that foliar applications of brassinosteroid to sweet cherry increased fruit quality by increasing fruit anthocyanin content, organic acids, ascorbic acid, and phenol content. It also resulted in greater fruit weight, diameter and length increased by brassinosteroid foliar application. Results indicated that foliar application of brassinosteroid at swollen bud stage, increased fruit yield and improved fruit quality.

The effect of tested biostimulants foliar applications on sugars content in Washington Navel orange juice presented in Table (7). From this table, it was cleared that non reducing, reducing and total sugars percentages in fruit juice were affected by spraying all tested substances in both seasons. The highest values of sugars percentages obtained from fruits on tress sprayed with yeast extract in the two seasons without significant differences among different concentrations.

Table (7):Effect of Milagrow and yeast biostimulants on non-reducing sugar (\%), reducing sugar (\%) and total sugar (\%) during 2012 and 2013 seasons.

\begin{tabular}{|l|c|c|c|c|c|c|}
\hline \multirow{2}{*}{ Treatments } & \multicolumn{2}{|c|}{$\begin{array}{c}\text { Non reducing } \\
\text { sugar (\%) }\end{array}$} & \multicolumn{2}{c|}{$\begin{array}{c}\text { Reducing } \\
\text { sugar (\%) }\end{array}$} & \multicolumn{2}{c|}{ Total sugar (\%) } \\
\cline { 2 - 7 } & $\mathbf{2 0 1 2}$ & $\mathbf{2 0 1 3}$ & $\mathbf{2 0 1 2}$ & $\mathbf{2 0 1 3}$ & $\mathbf{2 0 1 2}$ & $\mathbf{2 0 1 3}$ \\
\hline Control & $5.29 \mathrm{c}$ & $5.30 \mathrm{c}$ & $3.26 \mathrm{c}$ & $3.37 \mathrm{c}$ & $8.56 \mathrm{~d}$ & $8.67 \mathrm{e}$ \\
\hline $\begin{array}{l}\text { Milagrow } \\
\text { at 10 ppm }\end{array}$ & $6.57 \mathrm{~b}$ & $6.64 \mathrm{ab}$ & $3.91 \mathrm{~b}$ & $3.92 \mathrm{~b}$ & $10.49 \mathrm{c}$ & $10.56 \mathrm{~cd}$ \\
\hline $\begin{array}{l}\text { Milagrow } \\
\text { at 15 ppm }\end{array}$ & $6.60 \mathrm{ab}$ & $6.14 \mathrm{~b}$ & $3.94 \mathrm{~b}$ & $3.97 \mathrm{~b}$ & $10.54 \mathrm{c}$ & $10.11 \mathrm{~d}$ \\
\hline $\begin{array}{l}\text { Milagrow } \\
\text { at 20 ppm }\end{array}$ & $6.68 \mathrm{ab}$ & $6.66 \mathrm{ab}$ & $3.95 \mathrm{~b}$ & $4.01 \mathrm{~b}$ & $10.63 \mathrm{bc}$ & $10.67 \mathrm{bcd}$ \\
\hline $\begin{array}{l}\text { Yeast extract } \\
\text { at 1000 ppm }\end{array}$ & $6.72 \mathrm{ab}$ & $6.74 \mathrm{a}$ & $3.95 \mathrm{~b}$ & $4.05 \mathrm{~b}$ & $10.68 \mathrm{bc}$ & $10.80 \mathrm{bc}$ \\
\hline $\begin{array}{l}\text { Yeast extract } \\
\text { at 1500 ppm }\end{array}$ & $7.18 \mathrm{a}$ & $7.04 \mathrm{a}$ & $4.26 \mathrm{a}$ & $4.41 \mathrm{a}$ & $11.44 \mathrm{a}$ & $11.45 \mathrm{a}$ \\
\hline $\begin{array}{l}\text { Yeast extract } \\
\text { at 2000 ppm }\end{array}$ & $6.90 \mathrm{ab}$ & $6.92 \mathrm{a}$ & $4.19 \mathrm{ab}$ & $4.32 \mathrm{a}$ & $11.09 \mathrm{ab}$ & $11.24 \mathrm{ab}$ \\
\hline
\end{tabular}

Means followed by the same letter in each column are not significantly different at the 0.05 $\%$ level of probability according to Duncan's multiple range test.

In addition, the high concentration of Milagrow (20 ppm) did not show significant differences with the low concentration of yeast extract (1000 ppm) in the two seasons. The highest percentage of non-reducing sugars ( 7.18 and $7.04 \%)$ was determined in juice of fruits resulted from tress sprayed with $1500 \mathrm{ppm}$ yeast extract sprayed. On the other hand, the lowest non-reducing values (5.29 and $5.30 \%$ ) recorded with control fruits. Moreover, reducing and total sugars percentages take the same trend without significant differences among different concentrations of each tested biostimulants. 
Such findings are in agreement with these reported by EL-Shazly and Mustafa (3013) with Washington Navel orange who reported that active dry yeast caused a significantly increase in total sugars and vitamin $C$ contents of fruits. In the same lime, Abd El Hamied (2014) with Sukkary mango trees pointed to positive role of biostimulants including yeast extract in increasing total and non-reducing sugars. Concerning the effect of brassinolide on sugars content in citrus, Wang et al. (2004) reported that brassinolide increased sugars content of orange. On the other hand, Braun and Wild (1984) found that foliar application of brassinolide lead to decreasing in sugar content.

\section{REFERENCES}

Abd El-Motty, E. Z. and S. A. Orabi (2013). The beneficial effects of using zinc, yeast and selenium on yield, fruit quality and antioxidant defense systems in Navel orange trees grown under newly reclaimed sandy soil. Journal of Applied Sciences Research, 9(10): 6487-6497.

Abd El-Motty, E.Z.; M. F. M. Shahin; M. H. El-Shiekh and M. M. M. Abd-ElMigeed (2010). Effect of algae extract and yeast application on growth nutritional status, yield and fruit quality of Keitte mango trees. Agric. Biol. J. N. Am., 1(3): 421-429.

Abd El Hamied, S. (2014). Improving growth and productivity of "Sukkary" mango trees grown in North Sinai using extracts of some brown marine algae, yeasts and effective microorganisms 2-Productivity and fruit quality. Middle East Journal of Applied Sciences, 4(3): 460-470.

Abou El-Yazied, A. and M.A. Mady (2012). Effect of boron and yeast extract foliar application on growth, pod setting and both green pod and seed yield of broad bean (Vicia faba L.). J. Appl. Sci. Res., 8(2): 1240-1251.

Ahmed, F. F. and M.M. Ragab (2002). A new trial to stimulate growth and nutritional status of Picual olive transplants. The First International Conf. on olive cultivation, protection and processing, El Arish, Egypt, pp: 19-35.

AOAC (1995). Official methods of analysis. Association of Official Agricultural Chemists, $15^{\text {th }}$ Ed. Washington, DC, USA, pp: 490-510.

Atawia, A.A.R. and S.A. EL-Desouky (1997). Trials for improving fruit set, yield and fruit quality of Washington Navel orange by application of some growth regulators and yeast extract as a natural source of phytohormones. Annals of Agric. Sci. Moshtohor, 35(3): 1613-1632.

Attala, E.S.; A.M. El-Seginy and G.I. Eliwa (2000). Response of "Le- Conte" pear trees to foliar applications with active dry yeasts. J. Agric. Sci. Mans. Univ., 25(12): 7835-7841.

Barakat, M.R.; T.A. Yehia and B.M. Sayed (2012). Response of new hall Navel orange to bio-organic fertilization under newly reclaimed area conditions I: Vegetative growth and nutritional status. Journal of Horticultural Science \& Ornamental Plants, 4(1): 18-25. 
Braun, P. and A. Wild (1984). The influence of brassinosteroid on growth and parameters of photosynthesis of wheat and mustard plants. J. Plant Physiol., 116: 189-196.

Calvo, P.; L. Nelson and J.W. Klooper (2014). Agricultural uses of biostimulants. Plant Soil, 383: 3-41.

Dawood, M. G.; S. R. El-Lethy and M. Sh. Sadak (2013). Role of methanol and yeast in improving growth, yield, nutritive value and antioxidants of soybean. World Applied Sciences Journal, 26(1): 06-14.

Duncan, D.B. (1965). Multiple range and multiple F-test. Biometrics, 11: 1-42.

El-Shazly, S.M. and N.S. Mustafa (2013). Enhancement yield, fruit quality and nutritional status of Washington Navel orange trees by application of biostimulants. Journal of Applied Sciences Research, 9(8): 50305034.

Gabr, M. A.; M. A. Fathi; A. I. Mohamed and G. B. Mekhaeil (2011). Influences of some chemical substances used to induce early harvest of 'Canino' apricot trees. Nature and Science, 9(8): 59-65.

Gomes, M. M. A.; E. Campostrini; N. R. Leal; A. P. Viana; T. M. Ferraz; L. N. Siqueira; R. C. C. Rosa; A. T. Netto; M. Nuñez-Vázquez and M. A. T. Zullo (2006). Brassinosteroid analogue effects on the yield of yellow passion fruit plants (Passiflora edulis f. flavicarpa). Scientia Horticulturae, 110: 235-240.

Hafez, O.M.; M.A. Saleh; E.A.M. Mostafa; M.S. El-Shamma and M.A. Maksoud (2014). Improving pollination efficiency, yield and fruit quality of two date palm cultivars using growth activator. Int. J. Agric. Res., 9(1): 29-37.

Hegab, M.Y; F.F. Ahmed and A.H. Ali (1997). Influence of spraying active dry yeast on growth and productivity of Valencia orange (Citrus sinensis). Producing of the $1^{\text {st }}$ Scientific Conference of Agricultural Sciences, Faculty of Agric. Assuit Univ., Assuit.

IbnMaaouia, S.; S. BenMansour-Gueddes; B. Dridi-Mouhandes and M. Denden (2012). 24-epibrassinolide enhances flower and fruit production of pepper (Capsicum annuum L.) under salt stress. Journal of Stress Physiology \& Biochemistry, 8(3): 224-233.

Ismaeil, F. H. M. and KH. A. Bakry (2005). Response of papaya plants to some chemical substances and yeast extract treatments. Egypt. J. Agric. Res., 2(1): 119-150.

Kabeel, H.; F.M. Abd El-atif and M.S.M. Baza (2008). Growth, fruiting and nutritional status of "Le-Cont" pear trees in response to mineral and humate fertilizers. Annals Agric. Sci. Moshtohor, 46(2): 139-156.

Kassem, H. A.; A. M. El-Kobbia; H. A. Marzouk and M. M. El- Sebaiey (2010). Effect of foliar sprays on fruit retention, quality and yield of Costata persimmon trees. Emir. J. Food Agric., 22(4): 259-274.

Khafagy, S.A.A.; N.S. Zaied; M.M. Nageib; M.A. Saleh and A.A. Fouad (2010). The beneficial effects of yeast and zinc sulphate on yield and fruit quality of Navel orange trees. World Journal of Agricultural Sciences, 6 (6): 635-638.

Krishna, P. (2003). Brassinosteroid-mediated stress responses. J. Plant. Gr. Regu, 22: 289-297. 
Ministry of Agriculture (2014). Bull. Agric. Economic and Statistics- Ministry of Agriculture and Land Reclamation of Egypt.

Mohamed, K.A.H. and O.M. Hafez (2004). Effect of some foliar spraying of some yeast mutants on Valencia orange trees (Citrus sinensis). J. Agric. Mans. Univ., 29(4): 1995-2012.

Ranganna, S. (1979). Manual of analysis of fruit and vegetable Products,Central Food Technological Research Institute Mysore. Publishing Company Limited New Delhi, pp: 634.

Roghabadi, A.R. and Z. Pakkish (2014). Role of brassinosteroid on yield, fruit quality and postharvest storage of 'Tak Danehe Mashhad' sweet cherry (Prunus avium L.). Agricultural Communications, 2(4): 49-56.

Saleh, M.A.; M.S. El-Shamma; O.M. Hafez; E.A. Mostafa and M.M. Naguib (2014). Improving pollination process of Samani date palm cultivar using the bio-activator Milagrow stimcrop. IJPSS, 3(10): 1200-1209.

Sasse, J.M. (2003). Physiological actions of brassinosteroids: an update. J. Plant. Gr. Regul., 22: 276-288.

Sotomayor, S.; J. Castro; N. Velasco and R. Toro (2012). Influence of seven growth regulators on fruit set, pollen germination and pollen tube growth of Almonds. Journal of Agricultural Science and Technology, B2: 1051-1056.

Villafane, V.E.; F.J.E. Munoze and H.R. Torres (1989). Flowering, growth and ripening of the orange Washington Valley citrus. Acts. Agronomica, Universidad-Nacional de Colombia, 39(3-4): 142-149.

Wang, C. F.; Y.You; F. L. X. Chen; J. Wang and J. Wang (2004). Adjusting effect of brassinolide and GA4 on the orange growth. Acta Agriculturae Jiangxiensis Universitatis, 5-22. 


\section{El-Boray,M.S. et al.}

تحسين المحصول وجودة الثمـار في البرتقـال أبو سـرة باستخدام الرش ببعض منشطات النمو الطبيعية.

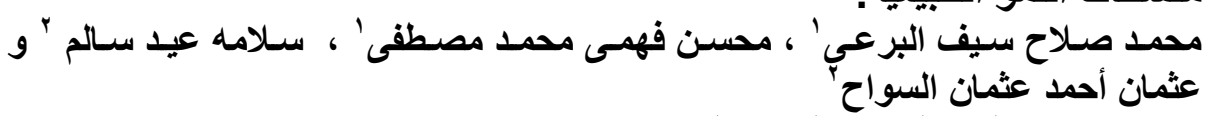

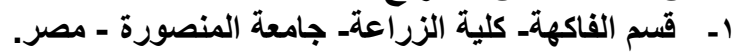

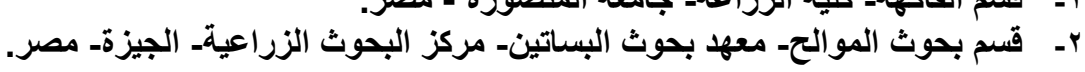

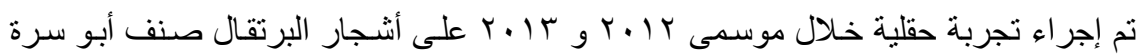

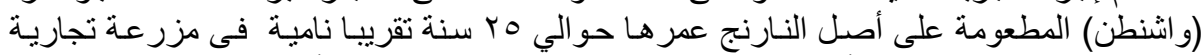

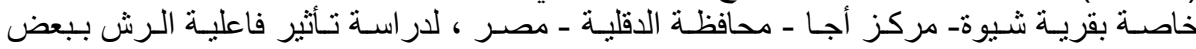

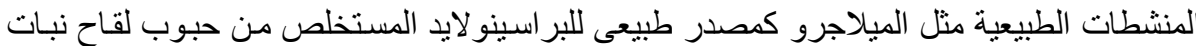

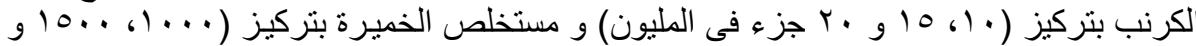

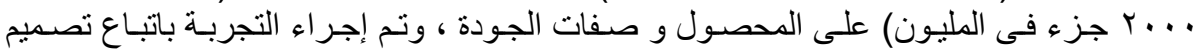

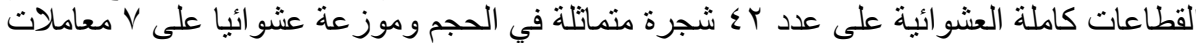

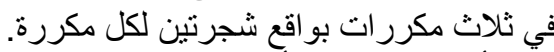

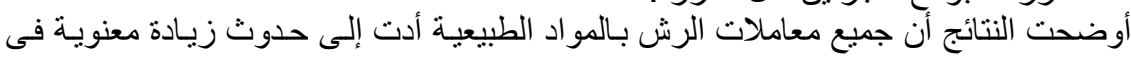

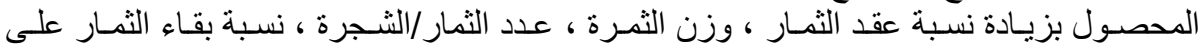

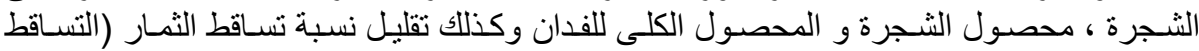

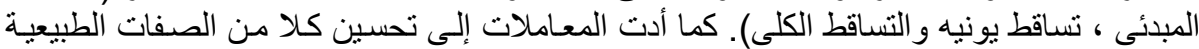

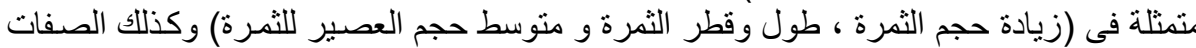

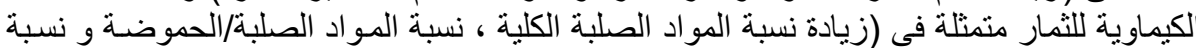

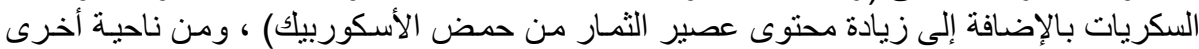

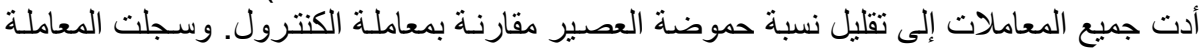

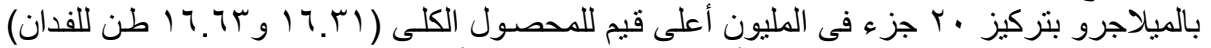

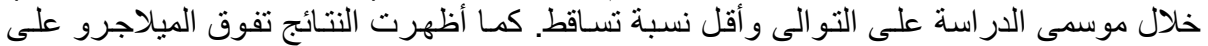

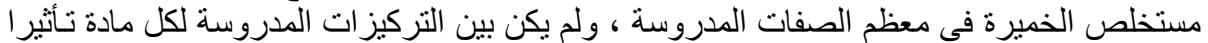

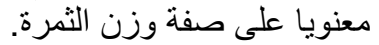

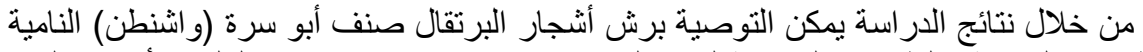

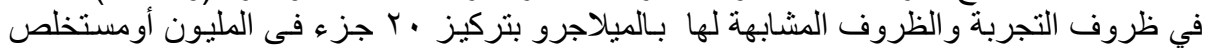

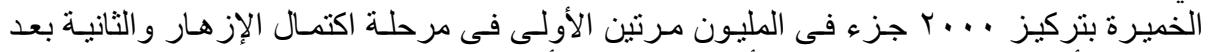
شهرمن الأولى وذللك للحصول على أعلى محصول و أفضل صفئل فئ جودة. 